Didaktik : Jurnal Pendidikan Guru Sekolah Dasar, ISSN : 24775673

Sekolah Tinggi Keguruan dan IImu Pendidikan Subang Volume IV Nomor 1, Juli 2018

\title{
PENENERAPAN MODEL PROBLEM BASED LEARNING (PBL) UNTUK MENINGKATKAN HASIL BELAJAR SISWA PADA SUBTEMA PELESTARIAN SUMBER DAYA ALAM INDONESIA
}

\author{
Tia Novialiswati ${ }^{1}$ \\ Acep Roni Hamdani ${ }^{2}$ \\ ${ }^{1}$ Mahasiswa FKIP Universitas Pasundan \\ 2Universitas Pasundan \\ ${ }^{1}$ tia.novialiswati66@gmail.com \\ ªcepronihamdani@unpas.ac.id
}

\begin{abstract}
This research is motivated by the problem of low student learning outcomes in class IV learning on the theme 9 My Country of Nature subtheme 3 Conservation of Natural Resources in Indonesia. The purpose of this study is to improve student learning outcomes in learning. This study uses a classroom action research method consisting of three cycles. The object of research is class IV SD Negeri 129 Rancasawo Margasari Bandung, as many as 25 people consist of 15 men and 10 women. The learning outcomes of the first cycle number of students who complete reached the KKM as many as 7 people or by $28 \%$ of the 25 students and students who have not yet completed reaching KKM as many as 18 people or by $72 \%$ of the total number of students. In the second cycle, students who reached the KKM were 21 people or $84 \%$ of the 25 students and students who did not reach the KKM by 4 people or by $16 \%$ of the total number of students. In the third cycle students who reach KKM as many as 24 people or $96 \%$ of 25 students and students who do not reach the KKM only 1 person or by $4 \%$ of the total students. The conclusion in this study is the application of the Problem Based Learning model can improve students and learning outcomes of fourth grade students of Public Elementary School 129 Rancasawo Margasari Bandung City on the theme 9 Kayanya Negeriku subema 3 Preservation of Natural Resource Wealth in Indonesia.
\end{abstract}

Keywords: Problem Based Learning Model, Learning Outcomes. 


\section{ABSTRAK}

Penelitian ini dilatar belakangi oleh permasalahan rendahnya hasil belajar siswa pada pembelajaran kelas IV pada tema 9 Kayanya Negeriku subtema 3 Pelestarian Kekayaan Sumber Daya Alam di Indonesia. Tujuan penelitian ini untuk meningkatkan hasil belajar siswa dalam pembelajaran. Penelitian ini menggunakan metode penelitian tindakan kelas yang terdiri dari tiga siklus. Objek penelitian adalah kelas IV SD Negeri 129 Rancasawo Margasari Kota Bandung, sebanyak 25 orang terdiri dari 14 orang laki-laki dan 11 orang perempuan. Hasil belajar siklus I jumlah siswa yang tuntas mencapai KKM sebanyak 7 orang atau sebesar $28 \%$ dari 25 siswa dan siswa yang belum tuntas mencapai KKM sebanyak 18 orang atau sebesar $72 \%$ dari jumlah keseluruhan siswa. Pada siklus II siswa yang mencapai KKM sebanyak 21 orang atau sebesar $84 \%$ dari 25 orang siswa dan siswa yang tidak mencapai KKM sebanyak 4 orang atau sebesar 16\% dari jumlah keseluruhan siswa. Pada siklus III siswa yang mencapai KKM sebanyak 24 orang atau sebesar $96 \%$ dari 25 orang siswa dan siswa yang tidak mencapai KKM hanya 1 orang atau sebesar $4 \%$ dari jumlah keseluruhan siswa. Kesimpulan dalam penelitian ini adalah penerapan model Problem Based Learning dapat meningkatkan siswa dan hasil belajar siswa kelas IV SD Negeri 129 Rancasawo Margasari Kota Bandung pada tema 9 Kayanya Negeriku subtema 3 Pelestarian Kekayaan Sumber Daya Alam di Indonesia.

Kata Kunci:Model Problem Based Learning, Hasil Belajar

\section{A. Pendahuluan}

Pendidikan dapat dimaknai sebagai proses perubahan tingkah laku peserta didik agar menjadi manusia dewasa yang hidup mandiri. Pendidikan tidak hanya mencakup intelektual saja, akan tetapi ditekankan pada proses pembinaan kepribadian peserta didik secara menyeluruh sehingga peserta didik menjadi dewasa. Pendidikan merupakan salah satu 
hal yang sangat penting untuk membekali mahasiswa dalam menghadapi masa depan. Di dalam Undang-Undang No 20 Tahun 2003 Tentang sistem pendidikan nasional pasal 3 disebutkan tentang tujuan pendidikan yakni mengembangkan potensi peserta didik agar menjadi manusia yang beriman dan bertakwa kepada Tuhan Yang Maha Esa, berakhlak mulia, sehat, berilmu, cakap, kreatif, mandiri serta menjadi warga negara yang demokratis juga bertanggung jawab.

Dalam meningkatkan mutu pendidikan adalah menjadi tanggung jawab semua pihak yang terlibat dalam pendidikan terutama bagi guru, yang merupakan ujung tombak dalam pendidikan dasar. Guru adalah orang yang paling berperan dalam menciptakan sumber daya manusia yang berkualitas yang dapat bersaing di zaman pesatnya perkembangan teknologi. Dalam setiap pembelajaran dapat menggunakan pendekatan, strategi, dan metode pembelajaran yang dapat memudahkan siswa dalam memahami materi yang dipelajarinya.

Undang-undang Republik Indonesia No.20 tahun 2003 tentang Sistem Pendidikan Nasional Bab II pasal 3, menyatakan bahwa: Pendidikan nasional berfungsi mengembangkan kemampuan dan membentuk watak serta peradaban banggsa yang bermartabat dalam rangka mencerdaskan kehidupan bangsa, bertujuan untuk berkembangnya potensi peserta didik agar menjadi manusia yang beriman dan bertaqwa kepada tuhan yang maha esa, berahlak mulia, sehat, berilmu, cakap, kreatif, mandiri, dan menjadi warga negara yang demokratis serta bertanggung jawab.

Pengertian Guru sebagai pendidik dan pengajar anak, guru diibaratkan seperti ibu kedua yang mengajarkan berbagai macam hal yang baru dan sebagai fasilitator anak supaya dapat belajar dan mengembangkan potensi dasar dan kemampuannya secara optimal,hanya saja ruang lingkupnya guru berbeda, guru 
mendidik dan mengajar di sekolah negeri ataupun swasta.

Menurut Undang-undang Republik Indonesia No. 14 Tahun 2005 tentang Guru dan Dosen. Guru adalah pendidik profesioanl dengan tugas utama mendidik, mengajar, membimbing, mengarahkan, melatih, menilai, mengevaluasi peserta didik pada pendidikan usia dini jalur pendidikan formal, pendidikan dasar, dan pendidikan menengah.

Kurikulum sudah banyak mengalami perubahan, yang mengakibatkan adanya penurunan kinerja para guru oleh karena itu guru harus mampu beradaptasi dengan banyak perubahan yang terjadi. Kurikulum 2013 dikembangkan berbasis pada kompetensi yang sangat diperlukan sebagai instrument untuk mengarahkan peserta didik menjadi: (1) manusia yang berkualitas yang mampu dan proaktif menjawab tantangan zaman yang berubah; (2) manusia terdidik yang beriman dan bertaqwa kepada Tuhan Yang Maha Esa, berakhlak mulia, sehat, berilmu, cakap, kreatif mandiri; (3) warga negara yang demokratis bertanggung jawab. Pengembangan kurikulum 2013 merupakan langkah kelanjutan pengembangan Kurikulum Berbasis Kompetensi yang telah dirintis pada tahun 2004 dan KTSP 2006 yang mencakup Kompetensi sikap, pengetahuan, dan keterampilan secara terpadu.

Kurikulum

2013 mengembangkan pembelajaran dengan pendekatan saintifik. Pendekatan saintifik merupakan proses pembelajaran yang dirancang sedemikian rupa agar siswa secara aktif mengamati, menanya, menalar, mengasosiasikan dan mengkomunikasikan. Pendekatan saintifik dimaksudkan untuk memberikan pemahaman kepada siswa dalam mengenal, memahami berbagai macam materi menggunakan pendekatan ilmiah, bahwa informasi bisa berasal dari mana saja, kapan saja,

Belajar menurut para ahli yang diungkapkan dalam strategi pembelajaran dengan Problem 
Based Learning itu perlu oleh Gagne, Briggs, dan Wager (1992, hlm. 3), belajar adalah serangkaian kegiatan dirancang untuk meningkatkan terjadinya proses belajar pada siswa.

Dalam proses belajar dalam strategi pembelajaran dengan problem based learning itu perlu menurut Reigeluth (1983, hlm. 20) memperlihatkan tiga hal, yaitu kondisi belajar yang mementingkan perhatian pada karakteristik pelajaran, siswa, tujuan dan hambatannya, serta apa saja yang perlu diatasi oleh guru. Dalam karakteristik belajar ini, perlu diperhatikan dalam pengelolaan pelajaran dan pengelolaan kelas. Hal ini terjadi pada waktu guru sedang memberi pelajaran kemudian ada siswa yang bercakap-cakap dengan temannya dan tidak memperhatikan pelajara, maka guru dapat menanyakan apa yang telah dipelajari siswa yang bersangkutan, agar siswa mau merperhatikan kembali pelajaran yang sedang disampaikan oleh guru.
Hasil belajar sebagai salah satu yang dapat terjadi dan dapat dijadikan sebagai indikator tentang nilai dari penggunaan suatu metode di bawah kondisi yang berbeda dalam strategi pembelajaran dengan problem based learning itu perlu menurut Reigeluth sebagaimana dikutip Keller dalam Rusmono adalah merupakan hasil belajar. Akibat ini dapat berupa akibat yang sengaja dirancang, karena itu merupakan akibat yang diinginkan dan bisa juga berupa akibat nyata sebagai hasil penggunaan metode pengajaran tertentu.

Hasil belajar menurut Bloom (1996, hlm. 35) merupakan perubahan perilaku yang meliputi tiga ranah, yaitu ranah kognitif, afektif, psikomotorik. Ranah kognitif meliputi tujuan-tujuan belajar yang berhubungan dengan memanggil kembali pengetahuan dan pengembangan kemampuan intelektuan dan keterampilan. Ranah afektif meliputi tujuan-tujuan belajar yang menjelaskan perubahan sikap, minat, nilai-nilai, dan pengembangan apresiasi serta 
penyesuaian. Ranah psikomotorik mencakup perubahan perilaku yang menunjukkan bahwa siswa telah mempelajarai keterampilan manipulatif fisik tertentu.

Model Problem Based Learning atau pembelajaran berdasarkan masalah merupakan model pembelajaran yang didesain menyelesaikan masalah yang disajikan. Menurut Arends (2008:41), PBL merupakan model pembelajaran yang menyuguhkan berbagai situasi bermasalah yang autentik dan bermakna kepada peserta didik, yang dapat berfungsi sebagai batu loncatan untuk investigasi dan penyelidikan. PBL membantu peserta didik untuk mengembangkan keterampilan berpikir kritis dan keterampilan menyelesaikan masalah.

Penggunaan

model pembelajaran yang bervariatif masih sangat rendah, guru yang jarang menggunakan media yang menarik sehingga pembelajaran sehingga pembelajaran tersebut siswa merasa jenuh, tidak bergairah dan bosan mengikuti pelajaran. Dalam kondisi tersebut guru tidak membiarkan berlangsung secara terus menerus, dengan kondisi tersebut guru mencari alternatif dalam pembelajaran. Salah satu upaya untuk meningkatkan hasil belajar, yaitu proses pembelajaran dibuat semenarik mungkin dengan menggunakan model pembelajaran Problem Based Learning yaitu pembelajaran yang menggunakan masalah dunia nyata sebagai konteks bagi siswa untuk belajar tentang cara berpikir kritis untuk memecahkan suatu masalah.

Peduli adalah sebuah nilai dasar dan sikap memperhatikan dan bertindak proaktif terhadap kondisi atau keadaan di sekitar kita. Peduli adalah sebuah sikap keberpihakan kita untuk melibatkan diri dalam persoalan, keadaan atau kondisi yang terjadi di sekitar kita. Orang-orang peduli adalah mereka yang terpanggil melakukan sesuatu dalam rangka memberi inspirasi, perubahan, kebaikan kepada lingkungan di sekitarnya. Ketika ia melihat suatu keadaan tertentu, ketika ia menyaksikan kondisi 
masyarakat maka dirinya akan tergerak melakukan sesuatu.

Apa yang dilakukan ini diharapkan dapat memperbaiki atau membantu kondisi di sekitarnya. Sikap peduli adalah sikap keterpanggilan untuk membantu mereka yang lemah, miskin, membantu mengatasi penderitaan, dan kesulitan yang dihadapi orang lain. Orang-orang peduli adalah orang-orang yang tidak bisa tinggal diam menyaksikan penderitaan orang lain. Sikap peduli adalah sikap yang terpanggil untuk mengajak dan mengingatkan orang-orang kaya yang selama ini lalai terhadap penderitaan orang-orang miskin yang ada di sekitarnya. Sikap peduli adalah sikap untuk pro aktif dalam mengatasi masalah-masalah di masyarakat dengan menggunakan dan memanfaatkan sumber daya yang ada di masyarakat.

Sikap peduli adalah sikap kesediaan untuk memberi solusi terhadap persoalan masyarakat. Agar masyarakat dapat mau berdonasi, agar masyarakat mau menyumbang, agar masyarakat memilih kerelawanan sehingga mau membantu kesulitan saudarasaudara kita. Peduli Adalah sikap untuk memperhatikan nilai-nilai kemanusiaan, selalu tergerak membantu kesulitan manusia lainnya. Sikap peduli adalah sikap untuk berusaha membangkitkan kemandirian yang ada di masyarakat. Orang-orang yang peduli adalah orang-orang yang tidak bisa tinggal diam, melihat kelemahan, sikap berpangku tangan dan membiarkan keadaankeadaan yang buruk terus terjadi di masyarakat. Sikap peduli adalah suatu sikap untuk senantiasa ikut merasakan penderitaan orang lain, ikut merasakan ketika penderitaan sebagian masyarakat lain sedang sakit, ikut merasa bersedih ketika sebagian saudara-saudara kita di timpa musibah bencana, kesulitan atau ditimpa keadaan-keadaan yang memberatkan dan membangkitkan rasa kasihan dan iba.

\section{B. Metode Penelitian}


Penelitian ini menggunakan metode Penelitian Tindakan Kelas (PTK). Metode yang digunakan dalam proposal penelitian ini adalah metode penelitian berbasis PTK (Penelitian Tindakan Kelas), dalam hal ini diajukan sesuai dengan masalah yang dihadapi dikelas yang harus diselesaikan. Hal ini didasari pada permasalahan yang ada dikelas terhadap upayanya meningkatkan hasil belajar siswa dalam kegiatan pembelajaran dengan menggunakan model problem based learning (PBL).

Subjek penelitian ini adalah siswa kelas IV SDN 129 Rancasawo Margasari Kota Bandung yang berjumlah 25 orang dengan perincian yaitu 14 orang siswa laki-laki dan 11 orang siswa perempuan dengan kemampuan yang berbeda-beda atau beragam antara siswa yang satu dengan siswa yang lain (tinggi, sedang, rendah).

Lokasi penelitian bertempat di SDN 129 Rancasawo Margasari Kota Bandung jl. Rancasawo No.50, Margasari, Buahbatu Kota
Bandung Jawa Barat sebagai tempat penelitian karena SD tersebut Kota Bandung jaraknya lebih dekat dengan rumah peneliti dan juga adanya kesedian untuk bekerjasama dari kepala sekolah dan guru kelas yang bersangkutan agar sekolahpun dapat mengembangkan model pembelajaran yang akan meningkatkan prestasi kinerja guru dan tercapainya tujuan pembelajaran dengan optimal. Setting penelitian ini berada disisi perkotaan yang berstatus ekonomi golongan menengah ke bawah yang masih banyak kekurangan dalam penggunaan pendekatan belajar yang menyebabkan siswa di kelas IV B di sekolah kurang aktif dalam pembelajaran.

Adapun alasan pemilihan subjek penelitian yaitu karena sekolah ini menggunakan kurikulum 2013 sehingga dapat memudahkan penelitian. Respon guru di kelas IV B yang sangat baik dapat membantu berlangsungnya penelitian ini. Selain itu, berdasarkan hasil observasi peneliti pada proses pembelajaran 
di kelas IV B hasil belajar siswa rendah. Peneliti berharap dapat meningkatkan hasil belajar siswa sehingga dapat mencapai KKM yang diharapkan dan diperlukan adanya perbaikan pada proses maupun hasil pembelajaran.

Objek Penelitian tindakan kelas ini adalah menggunakan model pembelajaran Problem Based Learning. Guru berperan sebagai pembimbing atau fasilitator bagi peserta didik dalam proses kegiatan belajar mengajar. Kegiatan pembelajaran yang diciptakan melalui model ini dapat dirancang sedemikian rupa dengan menyajikan suatu masalah sebagai langkah pembelajaran di kelas dengan memanfaatkan alat bantu yang telah ada di sekolah, lingkungan sekitar, sebagai pendukung proses pembelajaran atau menjadi sumber belajar.

Variabel-variabel penelitian yang menjadi fokus kajian penelitian ini terdiri dari tiga jenis variabel, antara lain:

1. Variabel Input yaitu variabel yang berkaitan dengan peserta didik, guru, bahan ajar, sumber belajar, prosedur evaluasi dan lingkungan belajar.

2. Variabel Proses yaitu variabel yang berkaitan dengan kegiatan pembelajaran yang telah dirancang yaitu penerapan model Problem Based Learning pada subtema Pelestarian Kekayaan Sumber Daya Alam di Indonesia untuk meningkatkan hasil belajar siswa kelas IV B SDN 129 Rancasawo Margasari Kota Bandung.

3. Variabel Output yaitu variabel yang berhubungan dengan hasil yang diharapkan setelah penelitian dilakukan, yakni peningkatan hasil belajar siswa kelas IV B SDN 129 Rancasawo Margasari Kota Bandung pada subtema Pelestarian Kekayaan Sumber Daya Alam di Indonesia.

\section{Hasil Penelitian dan}

\section{Pembahasan}

Berdasarkan hasil penelitian dapat diketahui adanya peningkatan hasil belajar dan sikap peduli lingkungan peserta didik setelah penerapan model Problem Based Learning pada subtema 
Pelestarian Kekayaan Sumber Daya Alam di Indonesia di kelas IV B SDN 129 Rancasawo Margasari. Peningkatan tersebut terlihat dari perhitungan hasil belajar dan sikap peduli lingkungan peserta didik yang diperoleh setelah dilaksanakannya tindakan siklus I, siklus II, dan siklus III yang masingmasing siklusnya terdiri dari dua kali pertemuan. Hasil penelitian dari siklus I, siklus II, dan siklus III dapat dijelaskan sebagai berikut.

\section{Rencana}

Pelaksanaan

\section{Pembelajaran (RPP)}

Berdasarkan rumusan masalah pada penelitian ini tentang bagaimana perencanaan pembelajaran disusun dengan menggunakan model pembelajaran problem based learning tipe numbered heads together, maka peneliti menyusun perencanaan sesuai dengan fase-fase yang terdapat pada model pembelajaran problem based learning tipe numbered heads together. Adapun fase-fase model pembelajaran tersebut menurut Ibrahim dan Nur dalam Rusman (2016, hlm. 243) adalah sebagai berikut:
Tabel 1. Langkah-langkah Model PBL

\begin{tabular}{|c|c|c|}
\hline Fase & $\begin{array}{c}\text { Indikat } \\
\text { or }\end{array}$ & $\begin{array}{c}\text { Tingkah } \\
\text { Laku Guru }\end{array}$ \\
\hline 1 & $\begin{array}{l}\text { Orientas } \\
\text { i siswa } \\
\text { pada } \\
\text { masalah }\end{array}$ & $\begin{array}{l}\text { Menjelaskan } \\
\text { tujuan } \\
\text { pembelajaran } \\
\text {, menjelaskan } \\
\text { logistik yang } \\
\text { diperlukan, } \\
\text { dan } \\
\text { memotivasi } \\
\text { siswa terlibat } \\
\text { pada aktivitas } \\
\text { pemecahan } \\
\text { masalah }\end{array}$ \\
\hline 2 & $\begin{array}{l}\text { Mengor } \\
\text { ganisasi } \\
\text { kan } \\
\text { siswa } \\
\text { untuk } \\
\text { belajar }\end{array}$ & $\begin{array}{l}\text { Membantu } \\
\text { siswa } \\
\text { mendefinisika } \\
\mathrm{n} \quad \text { dan } \\
\text { mengorganis } \\
\text { asikan tugas } \\
\text { belajar yang } \\
\text { berhubungan } \\
\text { dengan } \\
\text { masalah } \\
\text { tersebut }\end{array}$ \\
\hline
\end{tabular}


Didaktik : Jurnal Pendidikan Guru Sekolah Dasar, ISSN : 24775673

Sekolah Tinggi Keguruan dan IImu Pendidikan Subang

Volume IV Nomor 1, Juli 2018

\begin{tabular}{|c|c|c|}
\hline Fase & $\begin{array}{c}\text { Indikat } \\
\text { or }\end{array}$ & $\begin{array}{l}\text { Tingkah } \\
\text { Laku Guru }\end{array}$ \\
\hline 3 & $\begin{array}{l}\text { Membi } \\
\text { mbing } \\
\text { pengala } \\
\text { man } \\
\text { individu } \\
\text { al/kelom } \\
\text { pok }\end{array}$ & $\begin{array}{l}\text { Mendorong } \\
\text { siswa untuk } \\
\text { mengumpulk } \\
\text { an informasi } \\
\text { yang sesuai, } \\
\text { melaksanaka } \\
\text { n eksperimen } \\
\text { untuk } \\
\text { mendapatkan } \\
\text { penjelasan } \\
\text { dan } \\
\text { pemecahan } \\
\text { masalah }\end{array}$ \\
\hline 4 & $\begin{array}{l}\text { Menge } \\
\text { mbangk } \\
\text { an dan } \\
\text { menyaji } \\
\text { kan } \\
\text { hasil } \\
\text { karya }\end{array}$ & $\begin{array}{l}\text { Membantu } \\
\text { siswa dalam } \\
\text { merencanaka } \\
\mathrm{n} \text { dan } \\
\text { menyiapkan } \\
\text { karya yang } \\
\text { sesuai seperti } \\
\text { laporan, dan } \\
\text { membantu } \\
\text { mereka untuk } \\
\text { berbagai } \\
\text { tugas dengan } \\
\text { temannya }\end{array}$ \\
\hline
\end{tabular}

\begin{tabular}{|c|c|c|}
\hline Fase & $\begin{array}{c}\text { Indikat } \\
\text { or }\end{array}$ & $\begin{array}{l}\text { Tingkah } \\
\text { Laku Guru }\end{array}$ \\
\hline 5 & $\begin{array}{l}\text { Mengan } \\
\text { alisis } \\
\text { dan } \\
\text { mengev } \\
\text { aluasi } \\
\text { proses } \\
\text { pemeca } \\
\text { han } \\
\text { masalah }\end{array}$ & $\begin{array}{l}\text { Membantu } \\
\text { siswa untuk } \\
\text { melakukan } \\
\text { refleksi atau } \\
\text { evaluasi } \\
\text { terhadap } \\
\text { penyelidikan } \\
\text { mereka dan } \\
\text { proses yang } \\
\text { mereka } \\
\text { gunakan. }\end{array}$ \\
\hline
\end{tabular}

Sumber: Rusman (2016, hlm.

243)

Penilaian RPP dilakukan oleh observer terhadap peneliti bertujuanuntuk mengetahui apakah perencanaan yang dibuat oleh peneliti telah sesuai dengan fasefase yang ada ataukah masih ada kekurangan. Penilaian ini dilakukan pada setiap tindakan baik di dalam siklus I, II, maupun III. Pada Siklus I tindakan 1 mendapat nilai 83 dengan kategori baik dan pada tindakan 2 mendapat nilai 86 dengan kategori baik. Siklus II pada tindakan 1 mendapat nilai 90 dengan kategori sangat baik dan pada tindakan 2 juga memiliki 
kategori sangat baik dan mengalami peningkatan menjadi 93,3. Siklus III pada tindakan 1 mendapat nilai 96 dengan kategori sangat baik dan pada tindakan 2 juga memiliki kategori sangat baik dan mendapat nilai 96.

Berdasarkan data di atas dapat disimpulkan bahwa penilaian Rencana

Pelaksanaan

Pembelajaran (RPP) yang dilakukan oleh observer terhadap peneliti mengalami peningkatan yang signifikan pada setiap pertemuan dan setiap siklusnya.

\section{Kegiatan Belajar Mengajar (KBM)}

Berdasarkan rumusan masalah pada penelitian ini tentang bagaimana pelaksanaan kegiatan belajar mengajar disusun dengan menggunakan model pembelajaran problem based learning, maka peneliti menyusun pelaksanaan kegiatan belajar mengajar sesuai dengan langkah-langkah yang terdapat pada model pembelajaran problem based learning. Adapun fase-fase model pembelajaran problem based learning. Dari kekacauan ini siswa menggunakan berbagai kecerdasannya melalui diskusi dan penelitian untuk menentukan isu nyata yang ada. Langkah-langkah yang akan dilalui oleh siswa dalam sebuah proses PBL adalah: (1) menemukan masalah; (2) mendefinisikan masalah; (3) mengumpulkan fakta dengan menggunakan KND; (4) pembuatan hipotesis; (5) penelitian; (6) rephrasing masalah; menyuguhkan alternatif; dan (8) mengusulkan solusi.

Penilaian KBM dilakukan oleh observer terhadap peneliti bertujuan untuk mengetahui apakah pelaksanaan yang dibuat oleh peneliti telah sesuai dengan langkah-langkah yang ada ataukah masih belum sesuai. Penilaian ini dilakukan pada setiap tindakan baik di dalam siklus I, II, maupun III. Pada siklus I tindakan ke 1 perolehan hasil 67, dengan nilai 81 kategori sangat baik dengan persentase dan tindakan ke 2 memperoleh hasil 67 dengan nilai 81 kategori sangat baik. Siklus II pada tindakan 1 dan 2 juga memiliki kategori sangat baik jumlah 
perolehan hasil pada tindakan ke 1 yaitu 70 , dengan nilai 93 dan tindakan ke 2 memperoleh hasil 72 dengan nilai 96. Siklus III pada tindakan 1 dan 2 juga memiliki kategori sangat baik jumlah perolehan hasil pada tindakan ke 1 yaitu 73 , dengan nilai 97 dan tindakan ke 2 memperoleh hasil 74 dengan nilai 98. Pada setiap siklus ada perubahan yang positif. Sikap

\section{Peduli Lingkungan Peserta Didik}

Sikap terhadap obyek dan kejadian di lingkungan sekitardapat diperoleh jika aktifitas peserta didik tidak hanya mendengarkan ceramah guru saja. Sekolah khususnya kelas merupakan tempat untuk menumbuhkan karakter dan sikap di dalam diri siswa khusunya sikap peduli lingkungan, seperti pendapat Gede Raka, dkk dalam Skripsi Rini (2015, hlm. 36) bahwa pendidikan karakter di sekolah hendaknya memasukkan kepedulian terhadap lingkungan alam sebagai bagian dari tema pendidikan untuk menguatkan kesadaran dan tanggung jawab sebagai warga masyarakat, warga Negara, dan warga dunia yang baik.

Untuk menciptakan sikap tersebut maka guru menggunakan model pembelajaran problem based learning agar pembelajaran yang dilakukan berdasarkan permasalahan nyata yang harus dicari dan diolah secara mandiri oleh peserta didik bagaimana pemecahannya.Untuk mengetahui seberapa peduli peserta didik terhadap lingkungannya maka peneliti melakukan pengamatan yang dilakukan pada setiap siklus. Dengan rujukan teori menurut Nenggala dalam Skripsi Rini (2015, hlm. 37) berpendapat bahwa indikator seseorang yang peduli lingkungan adalah :

a. Selalu menjaga kelestarian lingkungan sekitar.

b. Tidak mengambil, menebang atau mencabut tumbuhtumbuhan yang terdapat di sepanjang perjalanan.

c. Tidak mencoret-coret, menorehkan tulisan pada pohon, batu-batu, jalan atau dinding.

d. Selalu membuang sampah pada tempatnya. 
e. Tidak membakar sampah di sekitar perumahan.

f. Melaksanakan

kegiatan membersihkan lingkungan.

g. Menimbun barang-barang bekas.

h. Membersihkan sampah-sampah yang menyumbat saluran air.

i. Dapat menjalankan jadwal piket kelas untuk menjaga kebersihan kelas.

Serta rujukan teori menurut Direktorat Pembinaan Sekolah Dasar dalam Skripsi Richka (2016, hlm. 25). Adapun indikator dalam sikap peduli lingkungan ini antara lain :

a. Menjaga keasrian, keindahan, dan kebersihan lingkungan sekolah.

b. Menunjukkan perhatian terhadap kebersihan kelas dan lingkungan sekolah.

c. Membuang sampah pada tempatnya.

d. Berpartisipasi dalam kegiatan sosial di sekolah.

e. Membersihkan alat praktik yang telah dipakai.

f. Membersihkan tangan setelah melakukan praktik. g. Tidak mencorat-coret meja atau dinding.

h. Memisahkan sampah organik dan sampah an-organik saat membuang sampah.

Berdasarkan kedua rujukan teori diatas peneliti menyimpulkan berfokus pada indikator sikap peduli lingkungan yaitu: 1)Siswa tidak mencoret-coret dinding, 2)Dapat menjalankan jadwal piket kelas untuk menjaga kebersihan kelas, 3) Membuang sampah pada tempatnya.

Dan hasilnya pada setiap siklus telah menunjukan adanya peningkatan yang signifikan terhadap sikap peduli lingkungan peserta didik.Pada siklus I peserta didik yang memiliki sikap peduli lingkungan berjumlah 13 orang (52\%), pada siklus II berjumlah 17 orang (68\%), dan pada siklus III berjumlah 21 orang (84\%). Sikap peduli lingkungan siswa terlihat melalui respon yang ditunjukkan oleh siswa selama pembelajaran berlangsung dimulai dari siklus I, II, hingga III. Terlihat respon siswa meningkat setiap siklusnya siswa mampu

melestarikan, 
mengindahkan, memperbaiki, menghiraukan dan memperhatikan segala sesuatu yang berada disekitarnya.

Berdasarkan uraian tersebut dapat disimpulkan bahwa sikap peduli lingkungan peserta didik sudah mencapai target yaitu 85\% sesuai yang diharapkan dengan rata-rata nilai pelaksanaan indikator lebih dari $80 \%$.

\section{Psikomotor Peserta didik}

Berdasarkan data yang ada bahwa untuk melihat hasil belajar peserta didik itu meningkat atau tidak bukan hanya dilihat dari aspek kognitifnya saja melainkan juga dari aspek psikomotor dan afektif. Sesuai dengan pendapat Bloom (Suprijono, 2015, hlm. 6) menyatakan bahwa hasil belajar mencakup: Kemampuan kognitif, afektif, dan psikomotorik. Domain kognitif adalah knowledge (pengetahuan, ingatan), comprehension (pemahaman, menjelaskan, meringkas, contoh), application (menerapkan), analysis (menguraikan, menentukan hubungan), synthesis (mengorganisasikan, merencanakan,

membentuk bangunan baru), dan evaluation (menilai). Domain afektif adalah receiving (sikap menerima), responding (memberikan respon), valuing (nilai), organization (organisasi), characterization (karakterisasi). Domain psikomotor meliputi initiatory, pre-routine, dan rountinized. Psikomotor juga mencakup keterampilan produktif, teknik, fisik, sosial, manajerial, dan intelektual.

Untukmenguji seberapa besar peningkatan psikomotor peserta didik peneliti mengujinya melalui observasi pada setiap pembelajaran dan ketika pembelajaran sedang berlangsung. Dari observasi tersebut akan diketahui apakah psikomotor peserta didik mengalami peningkatan pada setiap siklusnya. Dan dari pengujian tersebut diperoleh data yaitu pada siklus I peserta didik yang mencapai KKM sebanyak 11 orang dari 25 peserta didik atau jika dipersentasekan yaitu 44\%. Pada siklus II psikomotor peserta didik yang mencapai KKM sebanyak 16 orang 
dari 25 peserta didik jika dipersentasekan yaitu 64\%. Pada siklus III psikomotor peserta didik yang mencapai KKM sebanyak 20 orang dari 25 peserta didik jika dipersentasekan yaitu $80 \%$, sehingga dapat disimpulkan bahwa psikomotor peserta didik dari setiap siklusnya mengalami peningkatan yang signifikan.

\section{Hasil Belajar Peserta Didik}

\section{Berdasarkan} rumusan

masalah pada penelitian ini, tentang bagaimana peningkatan hasil belajar dengan menggunakan model pembelajaranproblem based. Maka dari itu, penulis berusaha menerapkan model tersebut untuk meningkatkan hasil belajar siswa dalam setiap siklus melalui permasalahan yang ada pada dunia nyata. Sehingga peserta didik nantinya akan memperoleh secara mandiri pengetahuan serta konsep dari materi yang diajarkan, sesuai dengan pendapatNurhadi, dkk (dalam Handayani, 2009) dari web Jurnal Hasil Riset http://www.ejurnal.com/2013/10/pengertian problem - based - learning -pbl.
Html diakses pada tanggal 19 Februari 2018.

Problem

Based Learning (PBL) adalah tipe pembelajaran dengan pendekatan pengajaran yang menggunakan masalah dunia nyata sebagai suatu konteks bagi siswa untuk belajar tentang cara berpikir kritis dan keterampilan pemecahan masalah, serta untuk memperoleh pengetahuan dan konsep yang esensial dari materi pelajaran.

Berdasarkan pengetahuan dan konsep yang telah diperoleh maka, untuk menguji seberapa besar pengetahuan dan konsep yang telah dikuasai oleh peserta didik peneliti mengujinya melalui penelitian tindakan kelas yang dilakukan sebanyak tiga siklus dengan menggunakan pretest dan posttest. Dari pretest dan posttest tersebut akan diketahui apakah hasil belajar siswa mengalami peningkatan pada setiap siklusnya. Dan dari pengujian tersebut diperoleh data yaitu pada siklus I peserta didik yang mencapai KKM sebanyak 15 orang dari 25 peserta didik atau jika dipersentasekan 
yaitu 60\%. Pada siklus II hasil belajar peserta didik yang mencapai KKM sebanyak 19 orang dari 25 peserta didik jika dipersentasekan yaitu $76 \%$. Pada siklus III hasil belajar peserta didik yang mencapai KKM sebanyak 21 orang dari 25 peserta didik jika dipersentasekan yaitu $84 \%$ sehingga dapat disimpulkan bahwa hasil belajar peserta didik dari setiap siklusnya mengalami peningkatan yang signifikan.

Data peningkatan hasil tes hasil belajar peserta didik siklus I, siklus II dan siklus III, dapat dilihat pada tabel berikut ini:

Tabel 2. Peningkatan Tes Hasil

Belajar

\begin{tabular}{|c|c|c|c|}
\hline Siklus & $\begin{array}{c}\text { Rata- } \\
\text { Rata } \\
\text { Nilai }\end{array}$ & $\begin{array}{c}\text { Siswa } \\
\text { Yang } \\
\text { Tuntas }\end{array}$ & $\begin{array}{c}\text { Perse } \\
\text { ntase } \\
\%\end{array}$ \\
\hline $\begin{array}{c}\text { Siklus } \\
\text { I }\end{array}$ & 70.40 & 15 & $60 \%$ \\
\hline $\begin{array}{c}\text { Siklus } \\
\text { II }\end{array}$ & 78.40 & 19 & $76 \%$ \\
\hline $\begin{array}{c}\text { Siklus } \\
\text { III }\end{array}$ & 84.00 & 21 & $80 \%$ \\
\hline
\end{tabular}

Berdasarkan analisis data hasil belajar peserta didik menunjukkan adanya peningkatan hasil belajar peserta didik menggunakan model Problem Based Learning. Setelah menggunakan model Problem Based Learning hasil belajar peserta didik mengalami peningkatan. Hasil belajar peserta didik pada siklus I menunjukkan bahwa peserta didik yang tuntas yaitu sebanyak 15 peserta didik atau $60 \%$ dari 25 peserta didik nilai rata-rata 70.4. Pada siklus II menunjukkan bahwa peserta didik yang tuntas yaitu sebanyak 19 peserta didik atau $76 \%$ dengan nilai rata-rata 78.4. Pada siklus III menunjukkan adanyaa peningkatan bahwa peserta didik yang tuntas yaitu sebanyak 21 peserta didik atau $84 \%$ dengan nilai rata-rata 84 . Sehingga dapat disimpulkan bahwa hasil belajar peserta didik sudah mencapai target yang diharapkan.

6. Hambatan yang dialami oleh guru dalam menggunakan model problem based learning

Setiap model pembelajaran memiliki hambatan tersendiri. Begitu pula terjadi dengan 
penggunaan model problem based lerning.Menurut Suyadi dalam skripsi Richka Nurjayanti (2016, hlm. 21), kekurangan model pembelajaran problem based learning yaitu:

a. Ketika siswa tidak memiliki minat tinggi, atau tidak mempunyai kepercayaan diri bahwa dirinya mampu menyelesaikan masalah yang dipelajari, maka mereka cenderung enggan mencoba.

b. Tanpa pemahaman "mengapa mereka berusaha" untuk memecahakan masalah yang sedang dipelajari, maka mereka tidak akan belajar apa yang mereka ingin pelajari. Artinya, perlu dijelaskan manfaat menyelesaikan masalah yang dibahasnya pada siswa.

c. Proses pelaksanaan problem based learning membutuhkan waktu yang lebih lama atau panjang, itu pun belum cukup, karena sering sekali siswa masih memerlukan waktu tambahan untuk menyelesaikan persoalan yang di berikan. Padahal waktu pelaksanaan problem based learning harus disesuaikan dengan beban kurikulum yang ada.

Berdasarkan data yang penulis peroleh dari wawancara guru, bahwa dalam melaksanakan proses pembelajaran ini terdapat beberapa hambatan diantaranya Hambatan yang dialami pada siklus I dalam menggunakan model problem based learning yaitu, Kesulitan dalam membangun suasana kelas yang kondusif, Kurangnya pengarahan guru saat proses diskusi kelompok, sehingga siswa mengalami kesulitan dalam merumuskan masalah dan pemecahannya.Hambatan pada siklus II yang diperoleh adalah kurang dalam hal pengkondisian waktu. Sedangkan hambatan yang ada pada siklus Illyaitu kurang efektif dalam penggunaan media pembelajaran. Pada siklus I terlihat cukup banyak hambatan yang dihadapi namun pada saat siklus II dan III hambatan-hambatan yang sering terlihat sudah mengalami penurunan seiring berjalannya waktu.

Akan tetapi, dari hambatan yang terjadi dalam proses 
pembelajaran model pembelajaran problem based learning terdapat keunggulan tersendiri diantaranya yaitu kegiatan pembelajaran lebih aktif dan menyenangkan. Hal ini terlihat dari meningkatnya partisipasi siswa dalam belajar yang meningkat pada siklus III. Hal itu tidak terlepas dari peranan guru dalam memberikan stimulus dan menyajikan materi agar lebih menarik bagi peserta didik sehingga lebih termotivasi untuk belajar.

Maka dari itu model pembelajaranproblem based learning yaitu model pembelajaran yang dapat memberikan pengalaman belajar yang nyata dan dapat mengembangkan kemampuan dan kreatifitas peserta didik baik secara individu maupun kelompok sehingga menjadikan pembelajaran lebih bermakna. Artinya, ketika satu masalah selesai di atasi, masalah lain muncul dan membutuhkan penyelesaian secepatnya.

\section{Upaya guru untuk mengatasi} hambatan

dalam

\section{menggunakan model problem}

\section{based learning}

Upaya untuk mengatasi hambatan atau kendala yang di alami oleh guru yaitu harus dapat mengembangkan pembelajaran problem based learning, artinya harus dapat mengembangkan model lainnya agar lebih menyenangkan selain dari model problem based learning. Sesuai dengan pendapat menurut Wina Sanjaya dalam Skripsi Hasni Farida Rahman(2016, hlm. 24), kelebihan model pembelajaran PBL sebagai berikut:

a. Pemecahan masalah merupakan teknik yang cukup bagus untuk memahami isi pelajaran.

b. Pemecahan masalah dapat menantang kemampuan siswa serta memberikan kepuasan untuk menemukan pengetahuan baru bagi siswa.

c. Pemecahan masalah dapat meningkatkan aktivitas pembelajaran siswa

d. Pemecahan masalah dapat membantu siswa bagaimana menstansfer pengetahuan 
mereka untuk memahami

masalah dalam kehidupan nyata.

e. Pemecahan masalah dapat mengembangkan pengetahuan baru dan bertanggung jawab dalam pembelajaran yang dilakukan oleh siswa.

f. Melalui pemecahan masalah bisa memperlihatkan kepada siswa bahwa setiap mata pelajaran (matematika, IPA, sejarah, dan lain sebagainya), pada dasarnya merupakan cara berfikir, dan sesuatu yang harus dimengerti oleh siswa, bukan hanya sekedar belajar dari guru atau dari buku-buku saja.

g. Pemecahan masalah dianggap lebih menyenangkan dan disukai siswa

h. Pemecahan masalah dapat mengembangkan kemampuan siswa untuk berpikir kritis dan mengembangkan kemampuan mereka untuk menyesuaikan dengan pengetahuan baru

i. Pemecahan masalah dapat memberikan kesempatan pada siswa yang mengaplikasikan pengetahuan yang mereka miliki dalam dunia nyata.

j. Pemecahan masalah dapat mengembangkan minat siswa untuk secara terus menerus belajar sekalipun belajar pada pendidikan formal telah berakhir.

Berdasarkan pendapat di atas dapat disimpulkan bahwa kelebihan Problem based learning yaitu model pembelajaran yang dapat memberikan pengalaman belajar yang nyata kepada peserta didik sehingga dapat mengembangkan kemampuan dan kreatifitas peserta didik baik secara individu maupun kelompok sehingga pembelajaran lebih bermakna, dan dapat pula mengembangkan konsep belajar secara terus-menerus. Artinya, ketika satu masalah selesai di atasi, masalah lain muncul dan membutuhkan penyelesaian secepatnya.

Upaya lain yang dapat dilakukan oleh guru adalah : a) Guru bukan hanya sebagai pembimbing akan tetapi juga sebagai fasilitator yang mengontrol dan mengatur serta dapat membangun suasana kelas lebih 
kondusif dan dapat memfasilitasi siswa, b) Guru harus berusaha mencari permasalahan menarik yang diketahui oleh siswa sehingga memudahkan siswa dalam merumuskan masalah dan dapat memotivasi siswa dalam pemecahan masalah, c) Guru harus lebih mengoptimalkan waktu pembelajaran secara lebih baik agar siswa dalam mengkaji materi ataupun dalam presentasi lebih baik lagi penampilannya, d) Guru harus lebih efektif dalam penggunaan media pembelajaran agar siswa menjadi lebih semangat dan tidak cepat bosan ketika belajar.

Hal ini harus menjadi perhatian bagi seluruh guru agar lebih kreatif lagi dalam mengembangkan metode yang dapat menarik perhatianpeserta didik untuk belajar sehingga saat melakukan kegiatan pembelajaran peserta didik tidak cenderung bosan dengan materi yang akan dibelajarkannya karena guru sudah memiliki kreativitas dalam mengembangkan model pembelajarannya.

\section{Kesimpulan}

Berdasarkan hasil penelitian tindakan kelas yang telah dilaksanakan untu kmeningkatkan hasil belajar siswa pada subtema Pelestarian Kekayaan Sumber Daya Alam di Indonesia di kelas IV B SDN 129 Rancasawo Margasari yang dilakukan sebanyak 3 siklus yaitu siklus I, II, dan III, serta berdasarkan seluruh pembahasan dan observasi yang telah dilakukan, penulis mengambil kesimpulan sebagai berikut: Dari perencanaan pembelajaran yang disusun oleh peneliti di kelas IV B SDN 129 Rancasawo Margasari, dapat diketahui bahwa dengan penerapan model pembelajaran Problem Based Learning dapat meningkatkan hasil belajar siswa dalam pembelajaran subtema Pelestarian Kekayaan Sumber Daya Alam di Indonesia.

1. Dari pelaksanaan pembelajaran sebelum menerapkan model PBL ini hasil belajar peserta didik ini kurang.

2. Dari pelaksanaan pembelajaran dengan model Problem Based Learning pada subtema 
Pelestarian Kekayaan Sumber Daya Alam di Indonesia dapat meningkatkan hasil belajar siswa di kelas IV B SDN 129 Rancasawo Margasari serta membuat peserta didik berperan aktif dalam memecahkan masalah.

3. Penilaian sikap peduli lingkungan peserta didik dengan menggunakan model pembelajaran Problem Based Learning pada subtema Pelestarian Kekayaan Sumber Daya Alam di Indonesia di kelas IV B SDN 129 Rancasawo Margasari terlihat adanya peningkatan.

4. Hasil Belajar peserta didik meningkat dengan menggunakan model Problem Based Learning pada subtema Pelestarian Kekayaan Sumber Daya Alam di Indonesia di kelas IV B SDN 129 Rancasawo Margasari. Hal ini terlihat dari setiap siklusnya, pada siklus I peserta didik yang mencapai KKM sebanyak delapan belas orang dari dua puluh delapan peserta didik dengan kategori nilai rata-rata cukup. Pada siklus Ilmengalami peningkatan, peserta didik yang mencapai KKM sebanyak dua puluh satu orang dari dua puluh delapan peserta didik dengan kategori nilai rata-rata baik. Peningkatan juga terlihat pada siklus III peserta didik yang mencapai KKM berjumlah dua puluh empat orang dari dua puluh delapan peserta didik dengan kategori nilai rata-rata baik.

Dari uraian di atas dapat ditarik kesimpulan bahwa penerapan model pembelajaran Problem Based Learning dapat meningkatkan hasil belajar dan sikap peduli lingkungan peserta didik pada subtema Pelestarian Kekayaan Sumber Daya Alam di Indonesia di kelas IV B SDN 129 Rancasawo Margasari.

\section{DAFTAR PUSTAKA}

Dalyono. (2010). Psikologi Pendidikan. Jakarta: Rineka Cipta 
Didaktik : Jurnal Pendidikan Guru Sekolah Dasar, ISSN : 24775673

Sekolah Tinggi Keguruan dan IImu Pendidikan Subang Volume IV Nomor 1, Juli 2018

Hasanah Siti Mariatul, (2017)

Penerapan Model Problem

Based Learning (PBL) Untuk

Meningkatkan Hasil Belajar

Siswa Pada Tema 9 Kayanya

Negeriku.

Iskandar, Dadang (2015).

Penelitian Tindakan Kelas dan

Publikasinya.

Muslich, Masnur. (2012),

Melaksanakan PTK (Penelitian

Tindakan Kelas) itu Mudah.

Jakarta: Bumi Aksara.

Panduan Penulisan Karya Tulis

IImiah (KTI) Fakultas Keguruan

dan IImu Pendidikan

Universitas Pasundan

Bandung 2018

Putria Yossi Dwi, (2017).

Penerapan model Kooperatif tipe talking stick untuk meningkatkan hasil belajar siswa pada subtema pelestarian lingkungan. Skripsi Unpas: tidak diterbitkan.

Rahma Hasni Farida (2016) dalam Dian Nurdiani Sudrajat (2017) Problem Based Learning tipe Numbered Heads Together. pada subtema pelestarian lingkungan. Pada Subtema Pelestarian Kekayaan Sumber Daya Alam di Indonesia. Skripsi Unpas: tidak diterbitkan.

Risydiani Nisa (2016) dalam Dian Nurdiani Sudrajat (2017) Problem Based Learning tipe Numbered Heads Together. pada subtema pelestarian lingkungan. Pada Subtema Pelestarian Kekayaan Sumber Daya Alam di Indonesia Skripsi Unpas: tidak diterbitkan 
Didaktik : Jurnal Pendidikan Guru Sekolah Dasar, ISSN : 24775673

Sekolah Tinggi Keguruan dan IImu Pendidikan Subang Volume IV Nomor 1, Juli 2018

$\begin{array}{ll}\text { Rusmono (2014), } \quad \text { Strategi } & \text { lingkungan. Pada Subtema } \\ \text { Pembelajaran dengan Problem } & \text { Pelestarian Kekayaan Sumber } \\ \text { Based Learning itu penting. } & \text { Daya Alam di Indonesia Skripsi } \\ \text { Bogor: Ghalia Indonesia } & \text { Unpas: tidak diterbitkan. }\end{array}$

Sudjana Nana, (2010). Cara Belajar

Suprijono (2013). Strategi

Siswa Aktif dalam proses Belajar

Pembelajaran dengan Problem

Mengajar

Based Learning itu penting.

Sudrajat Dian Nurdiani (2017)

Bogor: Ghalia Indonesia.

Problem Based Learning tipe Undang-Undang No. 20 tahun

Numbered Heads Together. 2003. Tentang Sistem Pendidikan

pada subtema pelestarian Nasional 